\title{
CKD-EPI Creatinine Formula
}

National Cancer Institute

\section{Source}

National Cancer Institute. CKD-EPI Creatinine Formula. NCI Thesaurus. Code C161338.

A formula to estimate glomerular filtration rate that takes into account sex, age, race, and serum creatinine $(\mathrm{SCr})$. eGFR(mL/min/1.73 m2)=141 $\times$ min $(\mathrm{SCr} / \mathrm{k}, 1) \wedge \mathrm{a} \times \max (\mathrm{SCr} / \mathrm{k}$, $1)^{\wedge}-1.209 \times 0.993^{\wedge} \mathrm{Age} \times 1.018$ [if female] $\times 1.159$ [if black] where: $\mathrm{SCr}$ is in $\mathrm{mg} / \mathrm{dL} ; \mathrm{k}=0.7$ for Female and 0.9 for Male; $a=-0.329$ for female and -0.411 for male. (Levey AS, Stevens LA, Schmid CH, Zhang YL, Castro AF, Feldman HI, Kusek JW, Eggers P, Van Lente F, Greene T. A new equation to estimate glomerular filtration rate. Ann Intern Med. 2009;150:604-612.) 